\title{
Planning for sustainable water supplies for US army installations
}

\author{
E. M. Jenicek ${ }^{1} \&$ D. F. Fournier ${ }^{2}$ \\ ${ }^{I}$ Engineer Research and Development Center, \\ U.S. Army Corps of Engineers, USA \\ ${ }^{2}$ Building Research Council University of Illinois, USA
}

\begin{abstract}
A key concern for the United States Army is the vulnerability of military installations to critical resource issues. In recent years, military installations have been impacted by conditions of increasing demand and decreasing supply of high quality fresh water. Urban growth adjacent to installations has combined with prolonged regional droughts to place key military missions at risk due to limited availability of this vital resource. Regional competition for water threatens continued availability of adequate water both on post and in adjacent urban areas. A series of recently completed studies comprise the first comprehensive review of long-term installation water sustainability. National watershed assessments provide a means to classify installations based on the health of the associated watersheds. Regional assessments provide the specific information necessary to formulate policy measures that can support a sustainable water future. These analyses - completed on a watershed level and projected over a 30 year time frame - include estimates of both installation and regional water demand. Assessments were completed for twelve Army bases across the United States and for three overseas installations. Results depict a range of installation water sustainability conditions that reflect the larger picture of water sustainability across the United States and around the world. The Army is applying the results of these studies to develop policies that will support sustainable long-term water supplies.
\end{abstract}

Keywords: water security, regional sustainability, water budget, water supply, water demand, water projection, climate change and water resources. 


\section{Introduction}

Fresh water is a fundamental requirement of life on earth. Though 70 percent of the planet's surface is covered in water, less than 3 percent is fresh; the rest is undrinkable seawater. Most of the fresh water is contained in glaciers and ice caps. The uneven global distribution of fresh water leaves one in six (1.1 billion) people without access to this necessity [1]. Water is such a critical resource that it was included in Millennium Development Goal 7, which is to "halve, by 2015 , the proportion of the population without sustainable access to safe drinking water and basic sanitation" [2]. As world population grows - estimated to reach more than 8 billion by 2030 - the urgency of water security will multiply.

Increasing demand, degraded supply, uneven distribution, and aging infrastructure are a few of the issues affecting water security - the capacity of a population to ensure that they continue to have access to potable water. Global climate change is projected to affect both water supply and distribution. Most of the large non-renewable reserves of groundwater are shared by neighboring nations and almost half of the Earth's land surface lies within international river basins $[3,4]$. The world's water is a collective resource and the potential for conflict is real.

The U.S. Army is vulnerable to the same issues of water supply and demand that jeopardize water security globally. Providing the required amount of clean fresh water in the location where it is needed is increasingly difficult. The conditions that exacerbate water availability are the aging condition of water infrastructure, generalized population growth especially in regions containing key Army installations, increased water demands for energy, and uncertain but generally agreed upon regional impacts of global climate change. The complexity of water compacts, treaties, and agreements is another challenge for Army installations. In the coming years, the impacts of water scarcity will be more severe in certain locations and this will be reflected in increasing costs.

\section{Background}

Department of the Army installations used over 219 million $\mathrm{m}^{3}$ (58 billion gallons) of potable water at a cost of $\$ 57.6 \mathrm{M}$ in fiscal year 2009 [5]. Water resource availability varies regionally and seasonally placing some Army installations in positions of water scarcity. Although water scarcity is a critical issue for drier regions, localized droughts are becoming more prevalent and extending for longer time periods. By the year 2015, it is estimated that 36 states will face serious water shortages [6]. A recent Army study [7] found that nearly 100 of the 411 installations included ( 23 percent) lie within watersheds that are highly vulnerable to water crisis situations.

Although individual studies have been completed as a result of localized threats to water supply, a comprehensive review of water sustainability at Army installations has not been previously performed. This assessment was accomplished in two phases. First, the national assessment identified categories of installations based on the "health" of the associated watersheds. This allowed 
regions to be prioritized for detailed analysis. Second, regional assessments evaluated total water supply and demand in regions containing installations projected over a 30 year time frame. This analysis was completed on a watershed level and includes estimates of installation water demand based on operational tempo, mission, and population. Regional assessments addressed the uncertainty inherent in water supply and demand projection by developing several plausible future water scenarios.

\subsection{Federal water conservation policy}

A complement of Federal water efficiency mandates have been promulgated in recent years. The Energy Independence and Security Act of 2007 requires comprehensive building audits, water efficiency retrofits, and measurement and verification of savings [8]. Executive Order (E.O.) 13423, also issued in 2007, mandates a $2 \%$ reduction in potable water consumption intensity through the year 2015 [9]. In 2009, the $2 \%$ annual reduction in water consumption was extended to the year 2020 by E.O. 13514, requiring an overall $26 \%$ reduction gained through water use efficiency and management [10]. E.O. 13514 also calls for the identification, promotion, and implementation of water reuse strategies that reduce potable water consumption, as consistent with State law. In addition to reducing potable water consumption, E.O. 13514 requires a $2 \%$ reduction annually, or $20 \%$ by the year 2020, in industrial, landscaping, and agricultural water consumption.

\subsection{Increasing demand}

The driving forces and pressures on water resources include both naturally occurring and human actions. Anthropogenic driving forces include population growth, demographic change including migration from rural to urban areas, increase in standard of living, competition between users, land-use change, and pollution of water resources. The natural variability of climate-induced distribution and occurrence of water make it difficult to predict the resource. One forecast presents a "business as usual" demand in 2030 of 6,900 billion $\mathrm{m}^{3}$. This compares to current global use of 4,500 billion $\mathrm{m}^{3}$ and is 40 percent above current, accessible, reliable supply [11].

The United States Army is also experiencing unprecedented growth, undergoing the largest organizational change since World War II. It is expected that fully one-third of the forces will be restationed by 2011 impacting 380,000 soldiers and family members. In addition, total Army strength is growing by 74,200 troops. This transformation is triggering 743 new building construction projects at a cost of $\$ 66.4 \mathrm{~B}[12]$.

\subsection{Decreasing supply}

Water tables are falling on every continent. Aquifer depletion is a global problem that has emerged in the last half century. It is only during this time period that the pumping capacity has existed to deplete aquifers. The size of the world water deficit - the amount of over-pumping in the world - using data for India, China, the Middle East, North Africa, and the United States - is estimated to be 
160 billion tons of water, which equals 160 billion cubic meters [13]. The United State's portion of the water shortfall is about 10.2 billion $\mathrm{m}^{3} / \mathrm{yr}(2,700$ billion gal/yr), about 7 percent of the total.

\subsection{Climate change}

Water resources are also subject to the impacts of global climate change. Climate change is projected to have a variety of effects on water resources including supply reliability, flood risk, health, agriculture, energy and aquatic systems. The main climate drivers that affect water are changing temperature and precipitation and rising global sea levels [14]. Specifically, increasing global temperature has the immediate effect of producing higher evaporation rates, thereby drying soils, increasing irrigation requirements of agriculture, and reducing reservoirs of surface water. Aquifer recharge will also fall, accelerating groundwater depletion. A range of changes to weather patterns are anticipated. These include both increased flooding and drought, sometimes within the same region, as storm events become larger and more seasonal. Coastal freshwater supplies are expected to decrease and become vulnerable to salinization. Reduced snowpack and glacier melt is expected to diminish water availability for seasonal demands [15]. In addition, earlier snowmelt will reduce surface water availability for lateseason agricultural needs.

Water resources in up to 70 percent of U.S. counties may be at risk due to climate change. More than 1,100 counties (one-third of counties in the lower 48) are at high or extreme risk of water shortages by mid-century as the result of global warming. That is, demand for water is expected to outstrip supplies at an accelerated climate-driven rate if no action is taken [16].

\subsection{Energy and water}

Approximately 40 percent of water use in the United States is used for energy production. This is largely non-consumptive cooling water for power generation plants. The total consumptive use is 3 percent. Trends away from once-through cooling and toward closed-loop cooling reduced the ratio of total water withdrawals to energy produced from $238 \mathrm{~m}^{3} / \mathrm{MWh}(63 \mathrm{gal} / \mathrm{kWh})$ during 1950 to $87 \mathrm{~m}^{3} / \mathrm{MWh}(23 \mathrm{gal} / \mathrm{kWh})$ in 2005 [17].

Renewable energy is one solution for increasing energy demand, concerns over imported oil, and the climate impacts of burning fossil fuel. Solving one resource problem can impact another if all implications are not considered. Examples of conflicts between renewable energy and water are not difficult to find. Exploiting a fault line beneath the Salton Sea in California to produce 2300 megawatts of geothermal power requires pumping water from the over allocated Colorado River [18]. Production of biofuels from irrigated crops can consume 15 to 30 times more water than it takes to produce a gallon of gasoline [19].

\subsection{Water infrastructure}

There are 240,000 water main breaks per year in the United States. Estimated water loss from distribution systems is 64 billion $\mathrm{m}^{3}$ (1.7 trillion gal) per year at 
a cost of \$2.6 billion per year [20]. The American Water Works Association targets 15 percent as a typical figure for unaccounted for water [21]. The American Society of Civil Engineer's Infrastructure Report Card gives drinking water a "D-." ASCE further identifies an annual shortfall of at least \$11 billion needed to replace facilities at the end of their useful life and to comply with existing and future water regulations [22].

The USEPA's Gap Analysis estimated that if water system investment remains static, the funding shortfall could exceed $\$ 500$ billion by $2020, \$ 263$ billion for Drinking Water capital costs [23].

Water system losses also carry a heavy energy burden. Southern California Edison estimates that energy savings in the range of 1,020,125 $\mathrm{MWh} /$ year are possible by addressing water system leaks. That amounts to about $26 \%$ of California's power generated by thermoelectric coal plants in 2008 [24].

\subsection{Water law}

Allocation of water in the United States is determined on the state level and is often based on decisions made during times of more plentiful supply and lower demand. These decisions are now considered overly optimistic, especially in light of coming climate change. An example of how these historical decisions play out in the $21^{\text {st }}$ century is the Law of the River, a set of collective agreements that divide the rights to the waters of the Colorado River among seven states. The main provisions were established in 1922 and currently allocate more rights than there is water available from the river.

Disputed water is becoming all too common in the United States. Over 95 percent of available freshwater resources in the United States cross state boundaries and are affected by compacts. Although there are 39 inter-state freshwater compacts in the United States, some areas, such as a part of the Mississippi River Basin, do not have compacts in place [25].

\section{National screening}

Army installations are widespread, located in a wide range of geographies and climate regimes. These studies examined water sustainability at twelve enduring Army installations in the United States and at overseas installations in Germany, Italy, and Korea. Many of the installations have experienced or are experiencing the challenges that accompany force transformation initiatives. In addition, each is subject to a unique set of regional stressors that affect water sustainability.

\subsection{Screening for watershed sustainability}

The national screening for watershed sustainability identifies watersheds that may be "at risk" for water supply or quality issues. Screening ranks watersheds by their relative vulnerability to such problems and flags those highly rated and that contain critical Army installations. Screening allows comparisons between regions through the use of national color-coded maps. 
Hydrologic data was obtained from the watershed application of the Sustainable Installations Regional Resource Assessment (SIRRA) tool [26]. SIRRA contains 17 indicators related to water supply and 10 indicators related to water demand. SIRRA calculates a rating for water demand, water supply, and overall watershed health. These ratings are mapped along with the 27 individual indicators. All indicators relate to the HUC8 watershed and that score is then applied to any Army installation lying within the watershed. Figure 1 shows the 10 United States study installations on the SIRRA map of overall watershed health. Eight of the 10 study installations are located in watersheds rated high vulnerability, vulnerable, or moderate vulnerability (Figure 1).

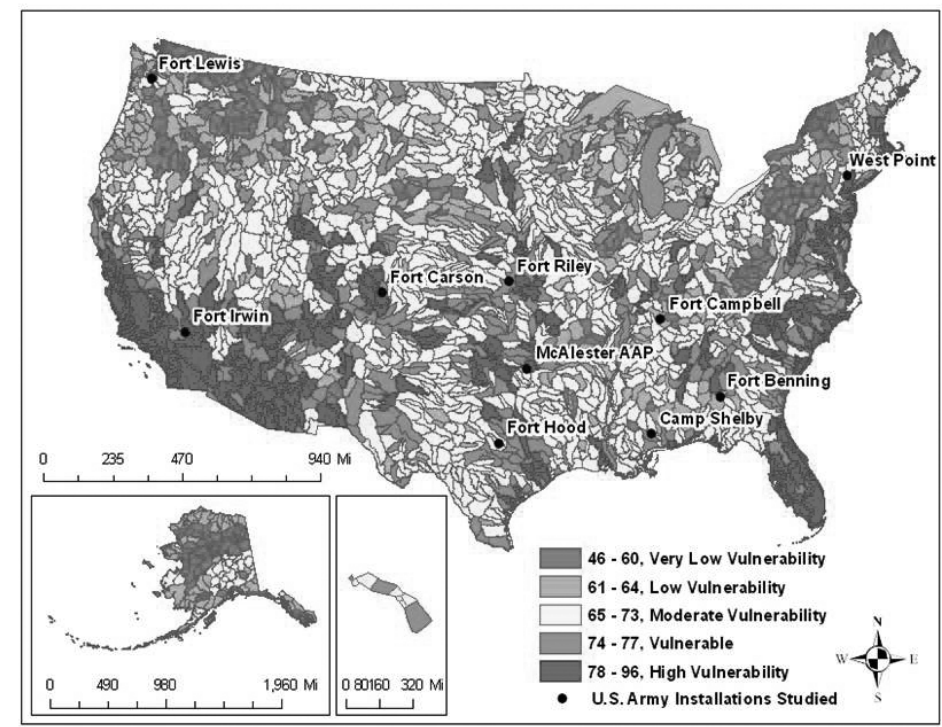

Figure 1: Study installations on map of overall watershed health.

\subsection{Selection of study sites}

The Army's initial regional water assessments were conducted for key installations that were projected to experience growth due to a series of Army transformation initiatives. Fort Bragg is already the largest Army installation by population and Fort Bliss is expected to triple in population by 2013. Both installations are critical to Army operations. It was also desirable to conduct studies in both arid and mesic regions, and in states with differing water laws.

Installations were selected for the follow-on study to achieve a diversity of geographic region, hydrologic parameters, primary military mission, and Army Major Command. An initial list of 20 installations was developed. Additional data was collected and analyzed to reduce this list to 10 final study installations in the United States and three overseas installations. 


\section{Regional assessments}

Installation water scarcity was assessed by applying methods for preparing a regional water budget. Regional water budgets identify sources of water supply and demand for the water resources used by Army installations. The product is an input-output model of regional water supply and demand. Model variables were altered to produce alternate future scenarios and evaluate the potential impact on availability of water for these Army installations.

The Installation Water Demand Model was used to develop water use estimates projecting at least 30 years into the future. The model includes installation-specific data about historic water consumption and existing and planned building stock to project future demand. Regional water demand is calculated using historic regional water consumption data, existing and planned water conservation measures, and projected population changes.

\subsection{Regional model}

Water budgets work on a spatial and temporal scale, both of which are determined based upon the level of detail required by the study. The spatial scale of the Army's water budget studies are regionally unique and are determined on an individual basis. As an example, the spatial scale of the region selected for the Fort Bliss-El Paso water balance includes the entire Rio Grande Aquifer System, that is, the Rio Grande River along with the two aquifers that are hydrologically connected to it and each other (Figure 2). The Mesilla Bolson and Hueco Bolson aquifers are labelled, as are the Rio Grande Project area, the water districts, and the dams and reservoirs that are components of the compacts, laws, and treaties that govern the region's waters.

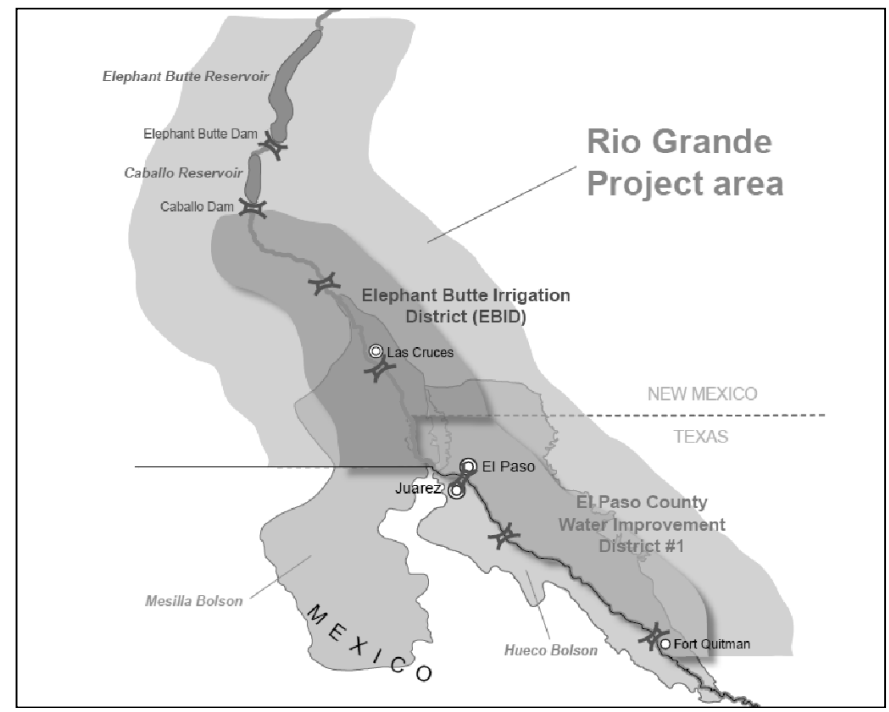

Figure 2: $\quad$ Fort Hood-El Paso regional assessment: definition of a region. 
Regional water budgets consider surface and groundwater supply along with total regional water demand. The interactions between hydrologic systems are identified when developing the regional water budget. These interactions are complex and in some cases can be difficult to quantify, especially in regions where little hydrologic data or studies are available. Additionally, larger trends that affect regional water budgets are identified; these include land use, climate patterns, and water management practices [27]. Due to the uncertainty inherent to these trends, a number of different future water scenarios are developed for each region.

\subsection{Installation model}

The Installation Water Demand Model uses customer disaggregation as the basis for projections. The key drivers for the water model are the installation building stock, permanent population, commuting population, industrial tempo, deployment tempo, rainfall and evapotranspiration data, and planned construction. Customer classes are residential, schools, industrial and maintenance, medical, administrative and moderate users, community and commercial, storage, high water use facilities, pools and vehicle wash facilities, irrigation, and losses. Sectoral demands were developed based on typical water consumption values and were calibrated to the installation footprint, population, and tempo of operations.

\subsection{Scenario planning}

Adopting a scenario-planning approach for the Army water assessments not only aids in problems of uncertainty, but allows for the creation of water budgets which are more useful to a wide variety of users. Different scenarios can be used to test the effects of diverse water management approaches or different climate change models. A standard set of scenarios can be applied across different installations that allow comparisons to be made between installation/regions. Each of the installation assessments included a climate change scenario.

\section{Fort Bliss case study}

Fort Bliss is a major Army installation covering 1.1 million acres on the edge of El Paso, Texas. Bliss' air defense artillery training ranges extend north into New Mexico. The installation is undergoing transformation that will increase its military population from 9,330 to 37,494 soldiers by 2013 . The Fort Bliss-El Paso region is located in the Chihuahuan Desert ecosystem. Rainfall is seasonal, falling largely in summer, and averages 10 inches annually.

Fort Bliss is close to El Paso with a population of over 700,000, and its sister city of Ciudad Juarez, Mexico, home to 1.4 million residents. El Paso is the nation's third fastest growing metropolitan area and is a regional focal point for trade and development. By 2050 the projected population for El Paso County is estimated to reach 1.5 million [28]. For Ciudad Juarez, which draws on the same water sources, the population by 2050 is expected to be over 3.2 million [29]. 
The water sustainability assessment projected regional supply and demand and installation demand from the base year of 2000 to 2040. Scenarios that were modelled are climate change, increased Juarez pumping, induced recharge, desalination, worst case scenario, and desalination absent climate change.

\subsection{Water system}

Fort Bliss is self-supplied through its own wells that draw on the Hueco Bolson Aquifer. El Paso Water Utilities serves as a back-up supply for the installation drawing on the Hueco Bolson, the Mesilla Bolson, and the Rio Grande River. Juarez also draws on all three water sources. The waters of the Rio Grande originate in Colorado and are appropriated through a complex web of interstate compacts and international agreements, stretching nearly 1,900 miles and serving as the border between Texas and New Mexico before discharging into the Gulf of Mexico. El Paso Water Utilities retains rights to the Rio Grande, as does Juarez. Fort Bliss is entitled to withdraw water from the Hueco Bolson according to Texas state law; aquifers may be pumped by anyone owning land over which the aquifer lies.

\subsection{Regional water budget}

Regional water demand in El Paso County is expected to grow by about $1 / 2$ percent per year by 2040 , to a consumptive use of 390 MGD $\left(1.47\right.$ million $\left.\mathrm{m}^{3}\right)$ with total withdrawals reaching 650 MGD $\left(2.46\right.$ million $\left.\mathrm{m}^{3}\right)$. The number of households in the region is expected to grow at the same rate as the population. Industrial uses are projected to remain constant. Agricultural uses are adjusted downward each year by $1 / 8$ percent of population growth due to loss of agricultural land to residential construction.

Regional water supply has a number of drivers. Flow in the Rio Grande is affected by dam releases, flow losses, El Paso Water Utility water rights, and the rationing of Rio Grande water during drought years. Water availability in the aquifers is based on the level of water recoverability and the change in storage. All water sources are affected by the projected impacts of climate change. Climate models of the southwestern United States show general agreement regarding anticipated climatic trends. As a result, more information is available regarding the impacts of climate change. The weighted average results of 17 global climate models [30] were analyzed to show an expected increase in temperature as well an estimated 12 percent decrease in precipitation (although this may range from 10-20 percent for the region).

\subsection{Installation model}

Fort Bliss' baseline water use for 2008 is 4.88 millions of gallons per day (MGD) $\left(18.5 \mathrm{~km}^{3}\right)$. This is projected to increase to 9.4 MGD $\left(35.6 \mathrm{~km}^{3}\right)$ by 2040, due to the increase in population and related construction of new facilities. Through a public-private partnership, Fort Bliss and El Paso Water Utility constructed a desalination plant to tap into the tremendous stores of brackish 
water in the Hueco Bolson, about 85 percent of the total. This plant is rated to produce a maximum capacity of 27.5 MGD $\left(104.1 \mathrm{~km}^{3} /\right.$ day) of fresh water. There is currently room for another $3.5 \mathrm{MGD}\left(13.2 \mathrm{~km}^{3} /\right.$ day $)$ expansion of the plant, for a total of $31 \mathrm{MGD}\left(117.3 \mathrm{~km}^{3} /\right.$ day) plant capacity. The plant is expected to double the effective life of the aquifer.

\subsection{Fort Bliss findings}

Fort Bliss' water future is tied closely with that of the El Paso/Juarez region. This region is already arid and probably will receive even less precipitation under global climate change scenarios. While scientific estimates of aquifer longevity differ, the aquifers are declining and are a limited non-renewable water supply. Existing El Paso Water Utility wells in the Hueco Bolson, Fort Bliss' source for self-supplied water, have been capped due to salinity and, the effect of pumping from new wells is unknown due to the complex subterranean structure of the aquifer. Fort Bliss' back-up water sources, through El Paso Water Utility, are the Mesilla Bolson, which is also declining, and the Rio Grande River.

Implementing a program of total water management can prepare an installation for fluctuations in water availability while easing the effects of extreme storm events. Total water management can also increase water security and independence through retention and reuse of both storm water and gray water where applicable. Decision-makers at Fort Bliss may readily draw on successful local approaches such as gray water reuse and aquifer recharge.

\subsection{Study findings}

The slate of 15 water sustainability studies gave a set of findings as diverse as the installations and regions themselves. Water issues are unique to location, though recurring concerns relate to water rights and the impact of climate on water availability. All results will be published in a series of technical reports.

\section{Conclusions}

Water security is becoming a significant issue across the United States Army. Installations, the communities that surround them, and the regions in which they are located are not water secure. Changes in water demand because of population variation from internal changes or migration, climate change, and ecosystem requirements will affect the ability of the Army to maintain and operate its installations. Limiting conservation efforts to only meeting mandated water use targets is insufficient for installations to be water secure. It is imperative that the Army develop a set of goals, objectives, strategies, performance measures, and commit resources to prevent water scarcity from degrading its mission.

Another complicating factor is that water is a resource that recognizes no boundaries - installation, municipal, county, region, state, and national - other than its own, that of watershed or sub-surface aquifer. People intervene in the natural hydraulic systems through inter-basin transfers, the movement of "virtual water" from one water region to another in products, and the increased 
withdrawals by water-intense industries. Planning for water sustainability is a regional issue requiring cooperation among multiple players whose collective decisions directly affect long-term availability or scarcity.

\section{References}

[1] WHO/UNICEF Joint Monitoring Programme for Water Supply and Sanitation, Water for life: Making it happen, World Health Organization: Geneva, 2005

[2] United Nations, 55/2 United Nations Millennium Declaration, 2000.

[3] United Nations Educational, Scientific and Cultural Organization (UNESCO) and International Association of Hydrogeologists (IAH), Internationally Shared Aquifer Resources Management Initiative (ISARM), 2010 .

[4] United Nations Environment Program. The Atlas of international freshwater agreements, UNEP: Nairobi, 2002.

[5] Department of the Army, FY 09 Annual Energy Management Report.

[6] U.S. Government Accountability Office, Natural Resources, Energy, and the Environment Challenges for the 21st Century, February 2005.

[7] Jenicek, Elisabeth M., N.R.D. Myers, D.F. Fournier, K. Miller, M. Hessel, R. Carroll, and R. Holmes, Army Installations Water Sustainability Assessment: an evaluation of vulnerability to water supply, ERDC/CERL: Champaign, September 2009.

[8] U.S. Congress, Energy Independence and Security Act of 2007, Public Law 110-140, $110^{\text {th }}$ Congress, December 19, 2007.

[9] The President, Executive Order 13423-Strengthening Federal Environmental, Energy, and Transportation Management, January 26, 2007.

[10] The President, Executive Order 13415-Federal Leadership in Environmental, Energy, and Economic Performance, October 8, 2009.

[11] 2030 Water Resources Group, Charting Our Water Future: Economic frameworks to inform decision-making, The Barilla Group, The Coca-Cola Company, The International Finance Corporation, McKinsey \& Company, Nestle S.A., New Holland Agriculture, SABMiller plc, Standard Chartered Bank, and Syngenta AG, 2009.

[12] Balocki, Col James, Army Growth and BRAC Update, Society of American Military Engineers Conference, May 22, 2008.

[13] Postel, Sandra. Pillar of Sand-Can the Irrigation Miracle Last? W.W. Norton \& Company: New York, 1999.

[14] Brekke, Levi D., J.E. Kiang, J.R. Olsen, R.S. Pulwarty, D.A. Raff, D.P. Turnipseed, R.S. Webb, and K.D. White, Climate change and water resources management: A Federal perspective, Circular 1331, U.S. Department of the Interior, U.S. Geological Survey: Reston, 2009.

[15] McKeown, Alice, and G. Gardner, Climate change reference guide. Update to State of the World 2009: Into a Warming World, Worldwatch Institute, 2009. 
[16] Roy, Sujoy, B.L. Chen, E. Girvetz, E.P. Maurer, W.B. Mills, and T.M. Grieb, Evaluating sustainability of projected water demands under future climate change scenarios, Natural Resources Defense Council: New York, 2010.

[17] Kenney, J.F., N.L. Barber, S.S. Hutson, K.S. Linsey, J.K. Lovelace and M.A. Maupin, Estimated use of water in the United States in 2005, U.S. Geological Survey Circular 1344, 2009.

[18] Institute of Electrical and Electronic Engineers, The Coming clash between water and energy. IEEE Spectrum, June 2010.

[19] Rogers, John and E. Spanger-Siegfried, The Energy-Water Collision, Catalyst, Union of Concerned Scientists, Fall 2010.

[20] USEPA, Addressing the Challenge Through Innovation, Aging Water Infrastructure Research Program, Office of Research and Development, National Risk Management Research Laboratory, EPA/600/F-07, USEPA/ORD/NRMRL: Cincinnati, September 2007.

[21] AWWA, Water audits and loss control programs, AWWA Manual M36, American Water Works Association: Denver, 2009.

[22] American Society of Civil Engineers, Report card for America's infrastructure, 2009.

[23] USEPA, The Clean Water and Drinking Water Infrastructure Gap Analysis, EPA/600/F-07, USEPA/ORD/NRMRL: Cincinnati, September 2002.

[24] Sturm, Reinhard, P. Thomas, and J. Lopez, The Link between Water Loss and Energy Consumption-Southern California Edison's Embedded Energy in Water Pilot, WaterSmart Innovations, Las Vegas, NV. 6-8 October 2010.

[25] Hall, N. and B.B. Stunz, U.S. water stewardship: A critical assessment of interstate watershed agreements, Watermark Initiative, 2009.

[26] Engineer Research and Development Center, Sustainable Installations Regional Resource Assessment. http://datacenter.leamgroup.com/sirra/.

[27] Lettenmaier, D., D. Major, L. Poff, and S. Running, The Effects of Climate Change on Agriculture, Land Resources, Water Resources, and Biodiversity, ed. M. Walsh, Synthesis and Assessment Product 4.3. U.S. Climate Change Science Program: Washington, D.C., 2008

[28] Far West Texas Planning Group, Far West Texas Water Plan, Prepared for the Texas Water Development Board, January 2006.

[29] Peach J. and J. Williams, Population Dynamics of the U.S.-Mexican Border Region, Unpublished, forthcoming SCERP Monograph, San Diego, 2003.

[30] Cai, Ximing, D. Wang, T. Zhu, and C. Ringler, Assessing the regional variability of GCM simulations. Geophysical Research Letters 36 (L02706). 